\title{
ORDER AMONG POWER OPERATOR MEANS WITH CONDITION ON SPECTRA
}

\author{
JadRAnka Mićić, Zlatko Pavić And Josip PeČARić
}

Abstract. As a continuation of our previous considerations about the order among power operator means [Linear Algebra Appl. 434 (2011), 1228-1237], we observe this order for other cases.

Mathematics subject classification (2010): 47A63, 47A64.

Keywords and phrases: Self-adjoint operator, positive operator, positive linear map, converses of Jensen's operator inequality, Mond-Pečarić method, power mean.

\section{REFERENCES}

[1] T. Furuta, J. Mićić Hot, J. PeČarić, Y. Seo, Mond-Pečarić Method in Operator Inequalities, Element, Zagreb, 2005.

[2] F.HANSEN, J.PEČARIĆ AND I.PERIĆ, Jensen's operator inequality and it's converses, Math. Scand. 100 (2007), 61-73.

[3] J.MIĆIĆ, Z.PAVIĆ AND J.PEČARIĆ, Jensen's inequality for operators without operator convexity, Linear Algebra Appl. 434 (2011), 1228-1237.

[4] J.MićIĆ AND J.PEČARIĆ, Order among power means of positive operators, II, Sci. Math. Japon. 71 (2010), 93-109.

[5] J.MićIĆ, J.PEČARIĆ AND Y.SEO, Function order of positive operators based on the Mond-Pečarić method, Linear Algebra Appl. 360 (2003), 15-34.

[6] J.MIĆIĆ, J.PEČARIĆ AND Y.SEO, Converses of Jensen's operator inequality, Oper. Matrices 4 (2010), 385-403.

[7] B.MOND, J.PEČARIĆ, Converses of Jensen's inequality for several operators, Revue d'analyse numer. et de thé orie de l'approxim. 23 (1994), 179-183.

[8] J.PEČARIĆ AND J.MIĆIĆ, Some functions reversing the order of positive operators, Linear Algebra Appl. 396 (2005), 175-187. 